\title{
Experimental Studies on Settlement Search of Piled Raft System
}

\author{
Kunal Kumar, P. P. Dahale, P. D. Hiwase
}

\begin{abstract}
Present study is an experimental work to analyse the effect of size of raft, length, number of piles on the settlement of the foundation system. In this work, study has been carried out to understand the load sharing ratio of the pile and raft with different patterns of pile and of different lengths. It was observed that, the load carrying capacity increases and settlement ratio reduces for the piled raft foundation tested on dry sandy soils deposits with relative density $70 \%$. Total 39 tests were carriedout for the different piled raft models of different raft sizes (15 $x 15$ $\mathrm{cm}, 17.5 \times 17.5 \mathrm{~cm}, 20 \times 20 \mathrm{~cm}$ ), number of piles (4 nos., 5 nos., 9 nos.) and of different pile lengths $(10 \mathrm{~cm}, 20 \mathrm{~cm}, 30 \mathrm{~cm}, 40 \mathrm{~cm})$. With the increase in raft size, load carrying capacity increased from $8.9 \mathrm{kN}$ (for $15 \mathrm{~cm}$ raft) to $10.54 \mathrm{kN}$ (for $17.5 \mathrm{~cm} \mathrm{raft}$ ), 17.22 $k N$ (for $20 \mathrm{~cm}$ raft) for $25 \mathrm{~mm}$ settlement. Length of pile considerably effect on the foundation settlement, for $5 \mathrm{kN}$ applied load, raft settlement $(15 \times 15 \mathrm{~cm})$ without pile was $10 \mathrm{~mm}$ which reduces to $3 \mathrm{~mm}, 2.4 \mathrm{~mm}, 1.8 \mathrm{~mm}$ and $1.4 \mathrm{~mm}$ for $10 \mathrm{~cm}, 20 \mathrm{~cm}$, $30 \mathrm{~cm}$ and $40 \mathrm{~cm}$ pile lengths respectively. Similar results were observed for other pile dimensions. Additionally, it is also observed that, pile number has considerable effect on the load carrying capacity and settlement of foundation system.

Keyword: Piled raft system, load shearing ratio, settlement reduction ratio
\end{abstract}

\section{INTRODUCTION}

The basic concept of piled raft foundation is to reduce the settlement of foundation system well below the allowable settlement and to transmit the loads from superstructures to the foundation soil. Friction piles are generally known as settlement reducers as the shaft capacity is mobilized at small settlement. The settlement reducing piles are generally used to decrease the total settlement of piles in case of rigid foundation and to reduce both total settlement and differential settlement in case of flexible rafts. In case of piled raft foundation in sandy soil, the entire load has to be taken by piles and raft acts as medium of transfer the load from the columns to the piles and raft has to withstand any hydraulic pressure that may act at the bottom of raft.

The piled raft can be designed to optimise the number of piles so as to get best results and not required to provide unnecessary piles. The piles are tactically spread in such a manner that, wherever the load is more and may cause settlement.

The present work is an extension of the work carriedout by Anjankar B. M. (2018) to study the settlement behaviour piled-raft foundation in dry sandy soil (with R. D. 70\%) by

Revised Manuscript Received on July 10, 2019.

Kunal Kumar, P.G Student, Department of Civil Engineering, Shri Ramdeobaba College of engineering and Management Nagpur 13, India (kunalsinghsrm2011@gmail.com)

Dr. P. P. Dahale, Assistant Professor, Department of Civil Engineering, Shri Ramdeobaba College of engineering and Management Nagpur 13, India (dahale.p.prasad@gmail.com)

Dr. P. D. Hiwase, Assistant Professor, Department of Civil Engineering, Shri Ramdeobaba College of engineering and Management Nagpur 13, India (hiwase.prashant@gmail.com) carrying out experimental work (i.e. load tests) on the piled raft model. The load transfer mechanism is also studied in the terms of load sharing ratio ( $\alpha \mathrm{PR})$. The combined piled raft foundation system provides a skillful concept wherein the applied load is transferred by means of a load sharing mechanism which is generated through a process of interaction between the soil, pile and raft. The piled raft foundation utilizes the pile group for the control of settlement, with the piles providing most of the stiffness at the service loads while the raft elements provide the additional capacity at the ultimate load levels. The reviewed literature shows the studies carried out in this direction in the part [Cooke (1986), Burland (1995), Poulos (2001), Bajad S.P (2008) Anjankar B.M. (2018)].

\section{TEST SETUP:}

Total 39 test combinations were planned for piled raft foundation system as given in the Table 2.1 for different sizes of raft and piles with different lengths and numbers. For experiments were conducted on galvanized iron rafts of $6 \mathrm{~mm}$ thickness and hollow piles of $12 \mathrm{~mm}$ diameter for testing. Sand blasting is done to roughen the surface of pile throughout the pile length. Piles were threaded at one end so that they can be easily screwed at one end to the raft model. Spacing between the piles kept between $40-60 \mathrm{~mm}$ corresponds to $2.5 \mathrm{~d}$ to $5 \mathrm{~d}$ respectively, where $\mathrm{d}$ is the pile diameter. Fig. 2.1 shows the piled raft foundation systems with different configurations of different patterns such as regular, square, diamond patterns with different raft size with different pile lengths $100 \mathrm{~mm}, 200 \mathrm{~mm}, 300 \mathrm{~mm}$ and $400 \mathrm{~mm}$.

Circular steel tank of $600 \mathrm{~mm}$ internal diameter and 800 $\mathrm{mm}$ height is used to carryout tests. Rain fall technique is adopted to fill sand in to the tank by controlling the flow and height of fall to have desired density of $16.20 \mathrm{kN} / \mathrm{m}^{3}$ throughout the tests. Proper measures are taken for insertion of piles vertically to avoid inclination in to the sand. Fig. 2.2 shows the test setup, wherein load is transferred to the piled raft assembly through plunger attached to the proving ring at the bottom. To measure the settlement of the foundation system, two dial gauges were placed on diagonally opposite ends of the raft. A calibrated proving ring of $50 \mathrm{kN}$ capacity is used to measure the load applied to the foundation system. Load is applied in increments and settlements are measured using dial gauges. 

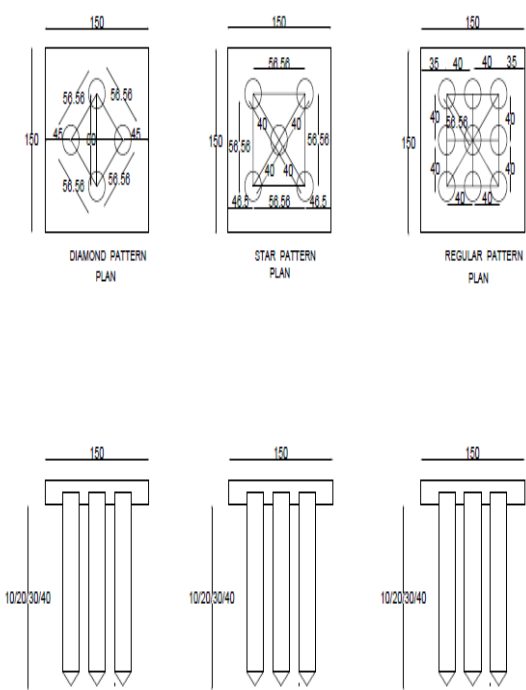

SECTION

SECTION

BECTON

ALDMESSONARE NMM

PLAN NOT TOSCALE

Fig 2.1: Configurations of piled raft model.

Table 2.1

Test Configuration and observation

\begin{tabular}{|c|c|c|c|c|c|c|}
\hline $\begin{array}{c}\text { Tes } \\
\mathbf{t} \\
\text { No. }\end{array}$ & & $\begin{array}{c}\text { Nos } \\
\text {. of } \\
\text { Pile } \\
\text { S } \\
\end{array}$ & $\begin{array}{l}\text { Pile } \\
\text { Len } \\
\text {-gth }\end{array}$ & $\begin{array}{l}\text { Patt } \\
\text {-ern }\end{array}$ & $\begin{array}{c}\text { Settle } \\
- \text { ment } \\
(\mathrm{mm})\end{array}$ & $\begin{array}{c}\text { Ulti- } \\
\text { mate } \\
\text { load } \\
\text { (in } k N)\end{array}$ \\
\hline \multicolumn{5}{|c|}{ Raft Size 15 x $15 \mathrm{~cm}$} & & \\
\hline 1 & \multicolumn{3}{|c|}{$\mathrm{C} 1$} & Raft & 25 & 8.9 \\
\hline 2 & \multirow{3}{*}{$\begin{array}{l}\mathrm{C} \\
2\end{array}$} & 4 & 100 & D1 & 10 & 10.7 \\
\hline 3 & & 5 & 100 & S1 & 10 & 10.8 \\
\hline 4 & & 9 & 100 & $\mathrm{R} 1$ & 10 & 11.91 \\
\hline 5 & \multirow{3}{*}{$\begin{array}{l}\mathrm{C} \\
3\end{array}$} & 4 & 200 & D2 & 20 & 15.27 \\
\hline 6 & & 5 & 200 & $\mathrm{~S} 2$ & 20 & 15.38 \\
\hline 7 & & 9 & 200 & $\mathrm{R} 2$ & 20 & 17.25 \\
\hline 8 & \multirow{3}{*}{$\begin{array}{l}\mathrm{C} \\
4\end{array}$} & 4 & 300 & D3 & 30 & 21.77 \\
\hline 9 & & 5 & 300 & S3 & 30 & 22.4 \\
\hline 10 & & 9 & 300 & R3 & 30 & 24.98 \\
\hline 11 & \multirow{3}{*}{$\begin{array}{l}\mathrm{C} \\
5\end{array}$} & 4 & 400 & D4 & 40 & 25.46 \\
\hline 12 & & 5 & 400 & S4 & 40 & 26.28 \\
\hline 13 & & 9 & 400 & R4 & 40 & 27.9 \\
\hline \multicolumn{7}{|c|}{ Raft Size $17.5 \times 17.5 \mathrm{~cm}$} \\
\hline 14 & \multicolumn{3}{|c|}{ C6 } & Raft & 25 & 10.54 \\
\hline 15 & \multirow{3}{*}{$\begin{array}{l}\mathrm{C} \\
7\end{array}$} & 4 & 100 & D5 & 10 & 13.58 \\
\hline 16 & & 5 & 100 & S5 & 10 & 13.98 \\
\hline 17 & & 9 & 100 & R5 & 10 & 17.36 \\
\hline 18 & \multirow{3}{*}{$\begin{array}{l}\mathrm{C} \\
8\end{array}$} & 4 & 200 & D6 & 20 & 17.94 \\
\hline 19 & & 5 & 200 & S6 & 20 & 19.54 \\
\hline 20 & & 9 & 200 & R6 & 20 & 20.2 \\
\hline 21 & \multirow{3}{*}{$\begin{array}{l}\mathrm{C} \\
9\end{array}$} & 4 & 300 & D7 & 30 & 21.43 \\
\hline 22 & & 5 & 300 & S7 & 30 & 24.3 \\
\hline 23 & & 9 & 300 & R7 & 30 & 24.68 \\
\hline 24 & \multirow{3}{*}{$\begin{array}{c}\mathrm{C} \\
10\end{array}$} & 4 & 400 & D8 & 40 & 26.86 \\
\hline 25 & & 5 & 400 & S8 & 40 & 28.03 \\
\hline 26 & & 9 & 400 & R8 & 40 & 29.2 \\
\hline
\end{tabular}

\begin{tabular}{|c|c|c|c|c|c|c|}
\hline \multicolumn{5}{|c|}{ Raft Size 20 × $20 \mathrm{~cm}$} & \multirow[b]{2}{*}{25} & \multirow[b]{2}{*}{17.22} \\
\hline 27 & $\mathrm{C} 1$ & & & Raft & & \\
\hline 28 & & 4 & 100 & D9 & 10 & 14.6 \\
\hline 29 & C & 5 & 100 & S9 & 10 & 15.68 \\
\hline 30 & & 9 & 100 & R9 & 10 & 18.4 \\
\hline 31 & & 4 & 200 & D10 & 20 & 19.1 \\
\hline 32 & C & 5 & 200 & $\mathrm{~S} 10$ & 20 & 20.2 \\
\hline 33 & & 9 & 200 & $\mathrm{R} 10$ & 20 & 22.3 \\
\hline 34 & & 4 & 300 & D11 & 30 & 27.25 \\
\hline 35 & C & 5 & 300 & $\mathrm{~S} 11$ & 30 & 28.8 \\
\hline 36 & 14 & 9 & 300 & R11 & 30 & 30.54 \\
\hline 37 & & 4 & 400 & D12 & 40 & 29.4 \\
\hline 38 & C & 5 & 400 & $\mathrm{~S} 12$ & 40 & 30.6 \\
\hline 39 & 15 & 9 & 400 & R12 & 40 & 31.5 \\
\hline
\end{tabular}

Note : D-Diamond, S-Star and R- Regular

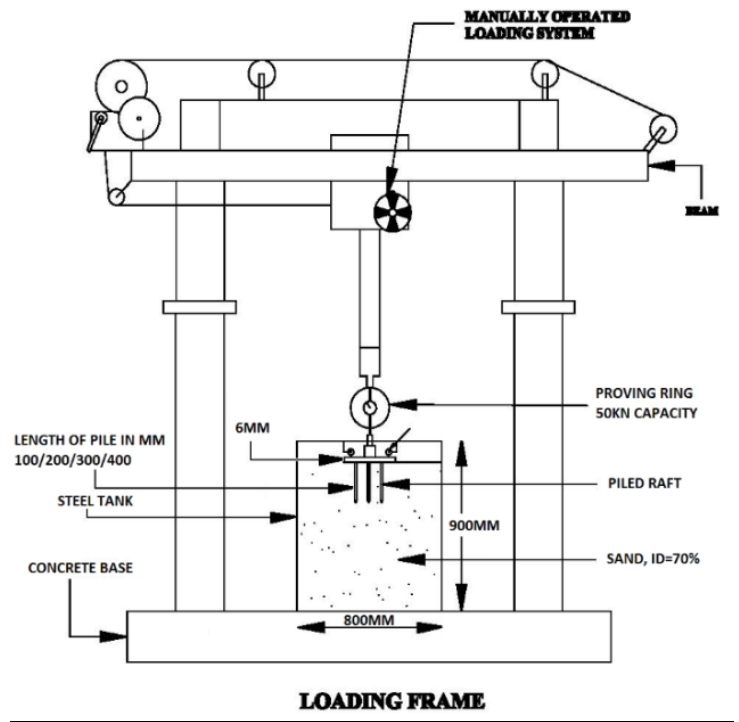

Figure 2.2 Experimental setup

\section{TEST RESULTS AND DISCUSSION}

\subsection{Effect of pile length.}

The pile length is varying as $100 \mathrm{~mm}, 200 \mathrm{~mm}, 300 \mathrm{~mm}$ and $400 \mathrm{~mm}$. It is observed that, as the pile length increases, the settlement decreases and thereby resulting into increase of load carrying capacity.

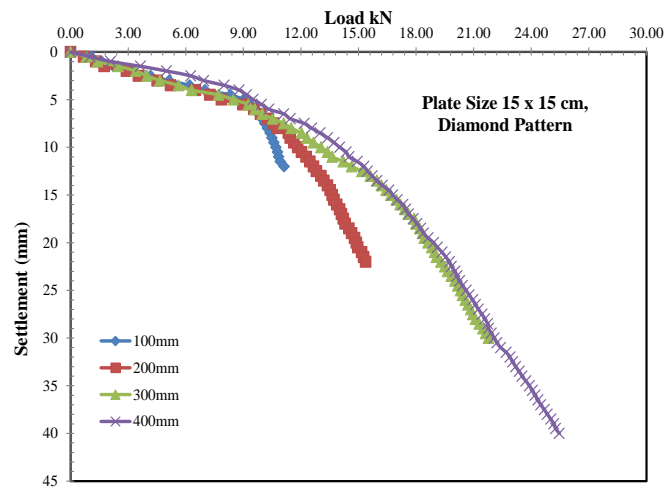

Fig. 3.1 Load-settlement curves for different pile lengths

Published By:

Blue Eyes Intelligence Engineering

\& Sciences Publication 


\subsection{Effect of number of piles on ultimate load capacity}

The ultimate load carrying capacity of the combined foundation system increases with the number of piles. Fig. 4.2 shows the effect of number of piles on ultimate load capacity

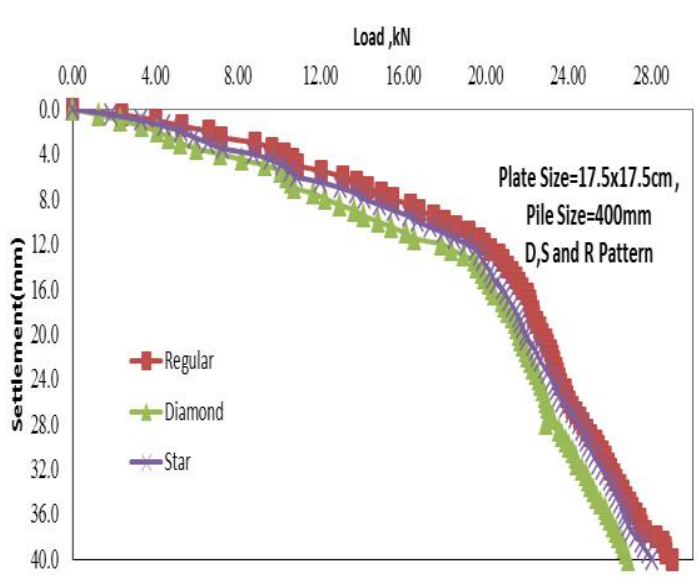

Fig. 3.2 Load-settlement curves for different patterns of same raft size and lengths

\subsection{Effect of plate size}

The plate size is varying as $15 \times 15 \mathrm{~cm}, 17.5 \mathrm{~cm} \times 17.5 \mathrm{~cm}$ and $20 \times 20 \mathrm{~cm}$. It is observed that, as the plate size increases, the settlement decreases and thereby resulting into increase of load carrying capacity.

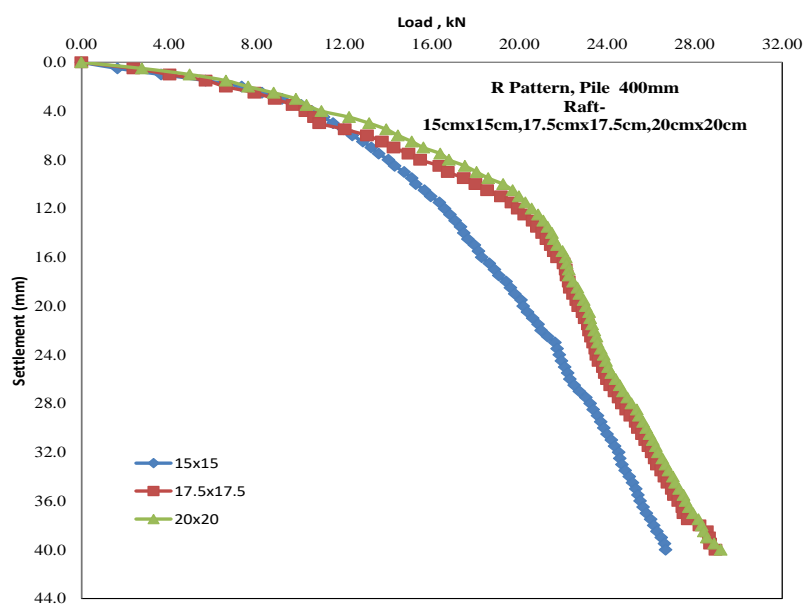

Fig 3.3 . Load Settlement Curve for different size of plate

\subsection{Effect of number of piles on settlement reduction ratio}

It is observed from the graph 6 that, as the length of pile increases settlement reduction ratio also increases. Also, with increase in the number of piles in piled raft foundation system, overall increase in the settlement reduction ratio is seen.

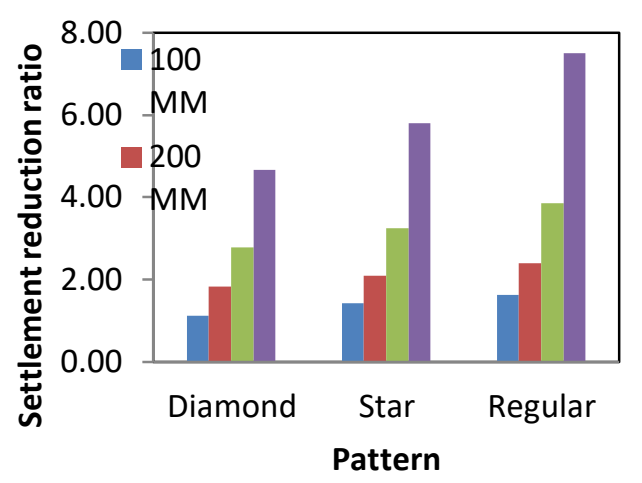

\section{Fig 3.4 :Settlement reduction ratio for different combinations and length of pile}

3.5. Effect of number of piles on load sharing

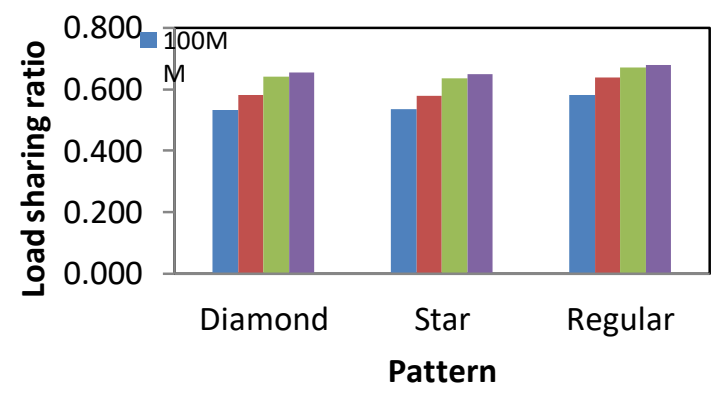

Fig 3.5: Load sharing ratio ( $\alpha$ PR) Vs. Number of piles

The effect of Pile length on settlement and load sharing mechanism: A 3x3 pile group is analysed with pile constant spacing for three different size of raft with three different pattern. The pile length is varying as $100 \mathrm{~mm}, 200 \mathrm{~mm}$, $300 \mathrm{~mm}$ and $400 \mathrm{~mm}$. It is observed that, as the pile length increases, the settlement decreases and thereby resulting into increase of load carrying capacity

\subsection{Effect of $L / B$ ratio on ultimate load capacity}

As the pile length increases, the total surface area for resistance is increased which produces significant increase in shear strength of soil and respective increase in ultimate load. Therefore, as L/B ratio increases, the ultimate load capacity increases.

\section{CONCLUSIONS}

Present study is on experimental investigation of pile raft system of load carrying capacity. In dry sandy soil deposit

- The Load carrying capacity increased with increase in size of raft i.e $150 \mathrm{~mm} \times 150 \mathrm{~mm}, 175 \mathrm{~mm} \times 175 \mathrm{~mm}$ and $200 \mathrm{~mm}$ x $200 \mathrm{~mm}$ size For $25 \mathrm{~mm}$ settlement was observed to be $8.9 \mathrm{kN}, 10.54 \mathrm{kN}$ and $17.22 \mathrm{kN}$ respectively. The bearing capacity of raft foundations on sand is always very high due to size effects where only raft is used as foundation

- Load carrying capacity of the piled raft system increases with increase in length of pile for example in case of Diamond pattern ( 4Nos of pile \& $150 \mathrm{~mm}$ x $150 \mathrm{~mm}$

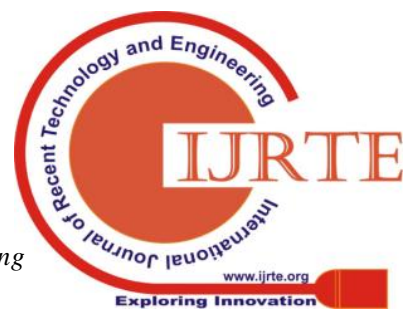


raft size) piled raft for $10 \mathrm{~mm}$ settlement of the foundation system, respectively $10.70 \mathrm{kN}, 11.83$ $\mathrm{kN}, 13.05 \mathrm{kN}, 14.02 \mathrm{Kn}$ loads applied on $100 \mathrm{~mm}$, $200 \mathrm{~mm}, 300 \mathrm{~mm}$ and $400 \mathrm{~mm}$ pile length. As the length of piles increases the load carrying capacity increases.

- The load bearing capacity of piled raft increases as the number of piles beneath the raft for example in case of Raft size $150 \mathrm{~mm} \times 150 \mathrm{~mm}$ ( $400 \mathrm{~mm}$ pile length)piled raft for $20 \mathrm{~mm}$ settlement of the foundation system , respectively $18.92 \mathrm{kN}, 19.74 \mathrm{kN}$, and $20.18 \mathrm{kN}$. The load bearing capacity of piled raft increases as the number of piles beneath the raft for example in case of Raft size $175 \mathrm{~mm} \times 175 \mathrm{~mm}$ ( 400mm pile length) piled raft for $20 \mathrm{~mm}$ settlement of the foundation system , respectively $21.58 \mathrm{kN}, 21.92 \mathrm{kN}$, and $22.70 \mathrm{kN}$ The load bearing capacity of piled raft increases as the number of piles beneath the raft for example in case of Raft size $200 \mathrm{~mm}$ x $200 \mathrm{~mm}$ ( $400 \mathrm{~mm}$ pile length) piled raft for $20 \mathrm{~mm}$ settlement of the foundation system , respectively $21.97 \mathrm{kN}, 22.41 \mathrm{kN}$, and $23.04 \mathrm{kN}$ load carrying capacity of piled raft increases as the number of piles beneath the raft increses.

- load sharing ratio for piled raft system(Raft size 150 $\mathrm{mmx} 150 \mathrm{~mm}, 100 \mathrm{~mm}$ pile length) for different pattern of same length of pile forPile Raft Diamond Pattern 100mm,Pile Raft Star Pattern 100mm, Pile Raft Regular Pattern $100 \mathrm{~mm}$ follows 0.533, 0.535 and 0.580 respectively for and it is shown that the load shared by the piles was found to be higher for pile raft with more number of piles.

- load sharing ratio for piled raft system (Raft size 150 $\mathrm{mm} \times 150 \mathrm{~mm}$ (D), it is observed that the load sharing ratio for different length with same pattern i.e Load shared by Pile Raft of Diamond Pattern $100 \mathrm{~mm}$, Pile Raft Diamond Pattern 200 mm, Pile Raft Diamond Pattern $300 \mathrm{~mm}$ and Pile Raft Diamond Pattern $400 \mathrm{~mm}$ is $0.533,0.581,0.640$ and 0.655 respectively, due to increase in length also the load sharing ratio increases.

- The settlement reduction ratio for raft $150 \mathrm{~mm}$ x $150 \mathrm{~mm}$ $(7-7.25 \mathrm{Kn})$ the Settlement reduction ratio for different pattern of same length i.e Diamond, Star and regular is as follows $1.13,1.43$ and 1.62 respectively and it is shown from the graph with increase in the number of piles in pile raft system, overall increase in settlement reduction ratio is seen. The number of piles beneath the raft increases gradually, the settlement reduction ratio.

- The settlement reduction ratio for raft $150 \mathrm{~mm}$ x $150 \mathrm{~mm}$ $(7-7.25 \mathrm{kN})$ for different length with same pattern i.e Pile Raft Diamond Pattern 100mm, Pile Raft Diamond Pattern 200 mm, Pile Raft Diamond Pattern $300 \mathrm{~mm}$ and Pile Raft Diamond Pattern $400 \mathrm{~mm}$ is $1.13,1.83,2.78$ and 4.67 respectively. It was observed that, the length of piles increases settlement reduction ratio increases.

\section{REFERENCES}

1. Clancy P et al, (1996)“Simple design tool for piled raft foundations", Geotechnique, 46, No.2,313-328.

2. Poulos H. G. et al(2001). "Piled raft foundations: Design and Applications", Geotechnique, 51, No.2, 95-113

3. Horikoshi Kenichi et al(2003): "Performance of piled raft foundations subjected to static horizontal loads", IJPMG,
International Journal of Physical Modelling in Geotechnics pp:37-50

4. Bajad S.P.et al, (2008) "An Experimental Study on behavior of vertically loaded piled rafts on soft clay",The 12th International Conference of International Association for Computer methods and Advances in Geomechaics Pp 84-91

5. Bunce Grahame et al, (2008)"Foundation design for the Burj Dubai-The world's Tallest Building"6th International Conference, Case history in geotechnical Engineering Arlington, VA, August 11-16

6. Pasts akorn Kitiyodom, (2011). "Approximate Numerical Analysis of large Piled Raft Foundation", soils and foundations, Japanese Geotechnical Society, Volume 51, No. 1,11 ,

7. Poulos H. G. et al (2011)., "Piled Raft Foundation for tall building", Geotechnical Engineering Journal of the SEAGS \& AGSSEA pp 78-84

8. PatilJaymin D. et al, "An experimental investigation on behavior of piled raft foundation" International journal of geomatics and geosciences, Volume 5, No 2 pp 300-311

9. Savio Angelinet et al (2015), "Performance of piled raft with varying pile length", 50thIndian Geotechnical Conference, pp $1-10$

10. ElwakilA. Z. (2016),, "Experimental and numerical analysis of piled raft system", Alexandria Engineering Journal, Vol. 10, 04-Special Issue pp 1231-1235

11. Oh. E. Y. N et al, "Parametric Study on Piled Raft Foundation in Sand Using Numerical Modelling", Griffith School of Engineering, Griffith University Gold Coast Campus, Queensland, Australia.pp 1-6

12. lamparuthiK. et al (2009)“Characterization of response of circular piled raft tested in sand” IGC,Guntur India. 989-995

13. ChandrawanshiSareesh, Kumar Rakesh and Jain P.K. et al,(2017), Settlement Characteristics of Soft Clay Reinforced With Stone Column: An Experimental Small Scale Study. International Journal of Civil Engineering and Technology, 8(5), pp. 937-948

14. Chandrawanshi Sareesh, Kumar Rakesh and Jain.P.K. (2017) et al Effect on Settlement Reduction Due to Method of Construction of Stone Column: An Experimental Small Scale Study. International Journal of Civil Engineering and Technology, 8(6), pp. 99-108

15. Anjankar B.M (2018).et al Experimental study on settlement behaviour of pile raft foundation in dry sandy soil International Journal of Civil Engineering and Technology (IJCIET) Volume 9, Issue 5, pp. 1229-1236 